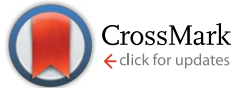

Cite this: RSC Adv., 2017, 7, 13467

Received 9th January 2017

Accepted 16th February 2017

DOI: $10.1039 / \mathrm{c} 7 \mathrm{ra00319f}$

rsc.li/rsc-advances

\section{Selective water-based oxychlorination of phenol with hydrogen peroxide catalyzed by manganous sulfate $\uparrow$}

\begin{abstract}
Hongchuan Xin, ${ }^{a}$ Shilei Yang, ${ }^{b}$ Baigang $A{ }^{\star b}$ and Zengjian $A n^{\star a}$
An efficient method for the selective oxychlorination of phenol to 2,4-dichlorophenol catalyzed by manganous(॥) sulfate is developed using hydrogen chloride as a chlorinating source, hydrogen peroxide as an oxidant and water as a solvent. The catalyst has high activity and selectivity under mild conditions. The products are automatically isolated from aqueous solution, which also contains the catalyst at the end of the reaction, and hence product separation and catalyst recycling are both simple in this system. The performance of manganous(॥) sulfate with the oxidative chlorinating system $\mathrm{HCl} / \mathrm{H}_{2} \mathrm{O}_{2}$ indicates that this is a promising synthetic method for the manufacture of various 2,4-dichlorophenol derivatives.
\end{abstract}

Chlorination of phenols is a key synthetic method because chloro-substituted phenols are essential materials in the synthesis of herbicides, pharmaceuticals, insecticides, dyes, etc. ${ }^{1,2}$ Among the various chloro-substituted phenols, main products include $p$-chlorophenol, $o$-chlorophenol, 2,4-dichlorophenol, 2,6-dichlorophenol and 2,4,6-trichlorophenol, which belong to a group named "light chlorophenols". ${ }^{3}$ In this group, 2,4-dichlorophenol is the most important material since it is an intermediate for 2,4-dichlorophenoxyacetic acid, a herbicide that is widely used in crops, rice and other massive cultivations. Traditional methods for the synthesis of 2,4-dichlorophenol usually involve electrophilic aromatic chlorination of phenol with chlorine gas (Scheme 1). $\cdot^{3-5}$ However, the utilization of chlorine atoms in these processes is quite low, nearly half of the chlorine is released as waste gas, which results in a waste of material and environment hazards. ${ }^{6,7}$

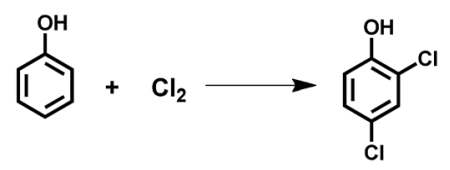

Scheme 1 Traditional methods for the synthesis of 2,4dichlorophenol.

${ }^{a}$ Key Laboratory of Biobased Materials, Qingdao Institute of Bioenergy and Bioprocess Technology, Chinese Academy of Sciences, 189 Songling Road, Qingdao 266101, China.E-mail:anzj@qibebt.ac.cn

${ }^{b}$ School of Chemical Engineering, University of Science and Technology Liaoning, Anshan 114051, China.E-mail: bgan@ustl.edu.cn

$\dagger$ Electronic supplementary information (ESI) available. See DOI: $10.1039 / \mathrm{c} 7 \mathrm{ra00319f}$
An alternative solution is oxidative chlorination, i.e. oxychlorination, which uses chloride anions as a chlorine source in the presence of an oxidant (Scheme 2) $\cdot^{7-12}$ In these systems, chloride anions are oxidized to chlorine by the oxidant and subsequently incorporated into the products. In general, chlorinating agents, such as sulfuryl chloride, ${ }^{4,13} N$-chlorosuccinimide, ${ }^{11,12}$ copper chloride ${ }^{14-16}$ titanium tetrachloride ${ }^{17}$ and $p$-toluene sulfonyl chloride, ${ }^{18}$ are used as chlorine sources, and reagents like sulfuric acid, ${ }^{19}$ perchloric acid, ${ }^{12,20}$ lithium diisopropylamide, ${ }^{18}$ dimethylsulfoxide, ${ }^{21}$ etc. ${ }^{22}$ are employed as oxidants. While the utilization of chlorine atoms in oxychlorination is remarkably increased compared to only half in traditional methods, further research is still required to use cheaper and environmentally friendly reagents.

Compared with most studies focused on the synthesis of monochloro-substituted phenols, ${ }^{4,23-28}$ the oxychlorination of phenols to 2,4-dichlorophenols is rather limited so far. ${ }^{3,20,29}$ For example, Gusevskaya et al. reported a method for aerobic oxychlorination of phenols over a $\mathrm{CuCl}_{2}$ catalyst, in which metal chlorides were used as chlorinating agents..$^{30,31} \mathrm{Feng}$ et al. found a microwave method for aerobic oxychlorination of phenols catalyzed by $\mathrm{CuCl}_{2}$ with hydrochloric acid as a chlorine source. ${ }^{23}$ However, these methods are exploited for the synthesis of $p$ chlorophenols. Notably, Ratnasamy et al. developed a promising method for the oxychlorination/oxybromination of aromatics including phenols over copper phthalocyanines

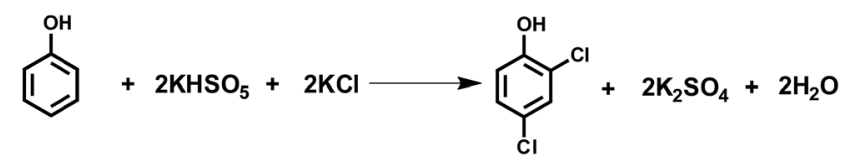

Scheme 2 Oxychlorination for the synthesis of 2,4-dichlorophenol. 


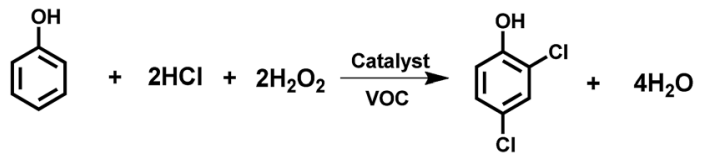

Scheme 3 Oxychlorination for the synthesis of 2,4-dichlorophenol with environmentally friendly oxidants.

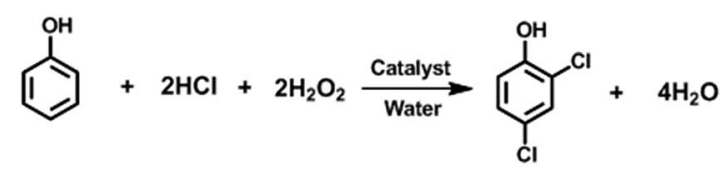

Scheme 4 Oxychlorination for the synthesis of 2,4-dichlorophenol with $\mathrm{H}_{2} \mathrm{O}_{2}$ in water.

Table 1 Results for the oxychlorination of 1a over various catalysts calculated from GC data ${ }^{a}$

\begin{tabular}{|c|c|c|c|c|c|c|c|}
\hline \multirow[b]{2}{*}{ Run } & \multirow[b]{2}{*}{ Catalyst } & \multirow[b]{2}{*}{ Conversion $^{b}(\%)$} & \multirow[b]{2}{*}{ Total yield $^{c}(\%)$} & \multicolumn{4}{|c|}{ Yield $^{d}(\%)$} \\
\hline & & & & $1 b$ & $p$ - & $o-$ & 1c \\
\hline $1^{e}$ & - & $<1$ & - & - & - & - & - \\
\hline 2 & - & 69 & 67 & $<1$ & 45 & 21 & - \\
\hline 3 & $\mathrm{NaCl}$ & 38 & 34 & $<1$ & 22 & 12 & - \\
\hline 4 & $\mathrm{CaCl}_{2}$ & 45 & 41 & $<1$ & 26 & 14 & - \\
\hline 5 & $\mathrm{MgCl}_{2}$ & 40 & 38 & $<1$ & 22 & 16 & - \\
\hline 6 & $\mathrm{ZnCl}_{2}$ & 36 & 33 & $<1$ & 19 & 14 & - \\
\hline 7 & $\mathrm{FeSO}_{4}$ & 54 & 51 & $<1$ & 41 & 10 & - \\
\hline 8 & $\mathrm{FeCl}_{3}$ & 61 & 55 & $<1$ & 33 & 22 & - \\
\hline 9 & $\mathrm{NiSO}_{4}$ & 56 & 40 & $<1$ & 25 & 15 & - \\
\hline 10 & $\mathrm{Co}(\mathrm{OAc})_{2}$ & 21 & 20 & $<1$ & 15 & 5 & - \\
\hline 11 & $\mathrm{Co}(\mathrm{acac})_{2}$ & 28 & 27 & $<1$ & 19 & 8 & - \\
\hline 12 & $\mathrm{LiCl}$ & 48 & 28 & $<1$ & 18 & 10 & - \\
\hline 13 & $\mathrm{Cu}\left(\mathrm{NO}_{3}\right)_{2}$ & 18 & 16 & $<1$ & 12 & 4 & - \\
\hline 14 & $\mathrm{Cu}(\mathrm{OAc})_{2}$ & 27 & 23 & $<1$ & 16 & 7 & - \\
\hline 15 & $\mathrm{CuBr}_{2}$ & 56 & 51 & $<1$ & 34 & 17 & - \\
\hline 16 & $\mathrm{CuCl}_{2}$ & 85 & 83 & $<1$ & 54 & 29 & - \\
\hline 17 & $\mathrm{MnSO}_{4}$ & 93 & 91 & 16 & 49 & 26 & Trace \\
\hline 18 & $\mathrm{MnCl}_{2}$ & 91 & 89 & 14 & 47 & 28 & Trace \\
\hline 19 & $\mathrm{Mn}\left(\mathrm{NO}_{3}\right)_{2}$ & 94 & 90 & 19 & 45 & 26 & Trace \\
\hline 20 & $\mathrm{MnO}_{2}$ & 67 & 65 & 8 & 38 & 19 & - \\
\hline
\end{tabular}

${ }^{a}$ Reaction conditions: 1a: $21.3 \mathrm{mmol}$, catalyst: $1 \mathrm{~mol} \%$, HCl: $151.3 \mathrm{mmol}, \mathrm{H}_{2} \mathrm{O}_{2}$ (30\% aq. solution): $4.05 \mathrm{ml}, 39.7 \mathrm{mmol}, \mathrm{H}_{2} \mathrm{O}$ : $9.8 \mathrm{ml}$, rt., 3 h. ${ }^{b}$ Conversion $(\%)=[$ the converted 1a $(\mathrm{mol}) /$ initial 1a $(\mathrm{mol})] \times 100{ }^{c}$ Total yield $(\%)=[$ all products $(\mathrm{mol}) /$ initial $\mathbf{1 a}(\mathrm{mol})] \times$ 100. ${ }^{d}$ Yield $(\%)=[$ target product $(\mathrm{mol}) /$ initial $1 \mathrm{a}(\mathrm{mol})] \times 100 .{ }^{e}$ No $\mathrm{H}_{2} \mathrm{O}_{2}$ was added.

encapsulated in zeolites with $\mathrm{HCl}$ and alkali chlorides/bromides as halogen sources and dioxygen and hydrogen peroxide as oxidants, ${ }^{32}$ but the selectivity for 2,4-dichloroaromatics was low. Moreover, VOCs (volatile organic compounds) are usually present in these systems (Scheme 3).

As for oxychlorination, we consider a desirable route for the chlorination of phenols with $\mathrm{HCl}$ using environmentally friendly oxidants, such as dioxygen or hydrogen peroxide, ${ }^{23,32,33}$ in which chlorine anions are incorporated into the product via oxidation and water is the only by-product from the oxidants.
On the other hand, the use of water as a solvent is particularly attractive because: (1) water is cheaper than VOC solvents; (2) the risk of explosions using a water-based system is much lower than that for systems containing VOCs; (3) 2,4-dichlorophenol is almost insoluble in water, and hence the product can be obtained by simple phase separation, which is convenient in application. However, this is a challenging topic, especially since catalytic methods for 2,4-dichlorophenol with high activity and selectivity have not been reported previously.

Herein, we present an efficient manganous(II) sulfatecatalyzed oxychlorination of phenol in water using the oxidative chlorinating system $\mathrm{HCl} / \mathrm{H}_{2} \mathrm{O}_{2}$ (Scheme 4). Complete conversion of phenol and high selectivity for 2,4-dichlorophenol are both achieved under mild conditions. To the best of our knowledge, this is the first report on selective water-based oxychlorination of phenol into 2,4-dichlorophenol in the liquid phase under VOC-free conditions.

In a typical reaction, phenol (1a) and a catalyst were added into water in a glass flask, and gaseous $\mathrm{HCl}$ was introduced to form a homogeneous solution. Then, 30\% of an aqueous solution of $\mathrm{H}_{2} \mathrm{O}_{2}$ was added to start the reaction. In the initial study, the molar ratio of $\mathrm{HCl}: \mathrm{H}_{2} \mathrm{O}_{2}: 1 \mathrm{a}$ at $7.1: 1.9: 1$ was used to screen the catalysts, and the results are shown in Table 1 . In the absence of $\mathrm{H}_{2} \mathrm{O}_{2}$, no reaction occurred even with a prolonged time (Table 1, run 1). When $\mathrm{H}_{2} \mathrm{O}_{2}$ was added in the absence of a catalyst, conversion of $1 \mathrm{a}$ reached $69 \%$ with a total yield of $67 \%$, the products were composed of $<1 \%$ of 2,4 -dichlorophenol (1b), $45 \%$ of $p$-chlorophenol $(p-)$ and $21 \%$ of $o$-chlorophenol $(o-)$ (Table 1, run 2). In the presence of $\mathrm{H}_{2} \mathrm{O}_{2}$, metal salts showed different activities. Among the tested metal salts, $\mathrm{NaCl}, \mathrm{CaCl}_{2}$, $\mathrm{MgCl}_{2}, \mathrm{ZnCl}_{2}, \mathrm{FeSO}_{4}, \mathrm{FeCl}_{3}, \mathrm{NiSO}_{4}, \mathrm{Co}(\mathrm{OAc})_{2}, \mathrm{Co}(\mathrm{acac})_{2}, \mathrm{LiCl}$, $\mathrm{Cu}\left(\mathrm{NO}_{3}\right)_{2}, \mathrm{Cu}(\mathrm{OAc})_{2}$ and $\mathrm{CuBr}_{2}$ had a poor effect (Table 1, run 315), as both the conversions and total yields were lower than those using $\mathrm{H}_{2} \mathrm{O}_{2}$ alone. Notably, $\mathrm{CuCl}_{2}$ and $\mathrm{MnSO}_{4}$ indicated high activities; the product distribution showed a dependence on the catalysts. A conversion of $85 \%$ for 1 a was obtained over $\mathrm{CuCl}_{2}$, the total yield was $83 \%$, containing $<1 \%$ of $\mathbf{1 b}, 54 \%$ of $p$ and $29 \%$ of $o$ - (Table 1 , run 16). Conversion of 1 a over $\mathrm{MnSO}_{4}$ reached as high as $93 \%$ with a total yield of $91 \%$, and the products were $16 \%$ of $1 \mathrm{~b}, 49 \%$ of $p$-, $26 \%$ of $o$ - and trace 2,6 dichlorophenol (1c) (Table 1, run 17). Obviously, $\mathrm{MnSO}_{4}$ is more effective in the formation of $\mathbf{1 b}$. Meanwhile, various manganese compounds were used, and the effect of anions on the reactions was tested (Table 1, run 18-20). Conversions and yields over $\mathrm{MnCl}_{2}$ and $\mathrm{Mn}\left(\mathrm{NO}_{3}\right)_{2}$ were comparable with those of $\mathrm{MnSO}_{4}$. Because the solubility of $\mathrm{MnO}_{2}$ in the solution was not good and some solid precipitate was always observed during the reaction, its activity was poor. These results indicated that anions had no effect on the reactions, and $\mathrm{Mn}^{2+}$ was key in this system.

Reactions over $\mathrm{MnSO}_{4}$ were optimized, and the results are listed in Table 2 . The effect of the catalyst was examined at a ratio of $\mathrm{HCl}: \mathrm{H}_{2} \mathrm{O}_{2}: \mathbf{1 a}=7.1: 1.9: 1$ (Table 2, run 1-3). As $\mathrm{MnSO}_{4}$ was varied from $1 \mathrm{~mol} \%$ to $10 \mathrm{~mol} \%$, 1a was completely converted at room temperature, the total yield decreased from $91 \%$ to $80 \%$, the yield of $1 \mathrm{~b}$ increased from $16 \%$ to $57 \%$, but the yield for $p$-decreased from $49 \%$ to $15 \%$ and $o$ - was from $26 \%$ to $8 \%$. In these processes, trace 1c was found. Obviously, over 5 
Table 2 Results for the optimization of reaction conditions calculated from GC data ${ }^{a}$

\begin{tabular}{|c|c|c|c|c|c|c|c|c|c|}
\hline Run & $\mathrm{MnSO}_{4}(\mathrm{~mol} \%)$ & $\begin{array}{l}T \\
\left({ }^{\circ} \mathrm{C}\right)\end{array}$ & $\begin{array}{l}\mathrm{HCl}: \mathrm{H}_{2} \mathrm{O}_{2}: \mathbf{1 a} \\
\text { (molar ratio) }\end{array}$ & Conversion $^{b}(\%)$ & Total yield $^{c}(\%)$ & \multicolumn{4}{|c|}{ Yield $^{d}(\%)$} \\
\hline 2 & 5 & 25 & $7.1: 1.9: 1$ & 100 & 82 & 55 & 16 & 9 & Trace \\
\hline 3 & 10 & 25 & $7.1: 1.9: 1$ & 100 & 80 & 57 & 15 & 8 & Trace \\
\hline 4 & 1 & 25 & $2.4: 1.9: 1$ & 76 & 74 & 9 & 39 & 25 & Trace \\
\hline $7^{e}$ & 1 & 80 & $2.4: 1.9: 1$ & 100 & 95 & 72 & 13 & 9 & 3 \\
\hline $8^{e}$ & 1 & 90 & $2.4: 1.9: 1$ & 100 & 83 & 65 & 11 & 5 & 2 \\
\hline $9^{f}$ & 1 & 80 & $2.4: 2.8: 1$ & 100 & 97 & 93 & 1 & Trace & 3 \\
\hline $10^{g}$ & 1 & 80 & $2.1: 2.8: 1$ & 100 & 95 & 91 & 1 & Trace & 3 \\
\hline $11^{g}$ & - & 80 & $2.1: 2.8: 1$ & 100 & 96 & 34 & 39 & 23 & Trace \\
\hline $12^{h}$ & - & 80 & $2.0: 2.0: 1$ & 94 & 91 & 31 & 35 & 25 & Trace \\
\hline
\end{tabular}

${ }^{a}$ Reaction conditions: 1a: $21.3 \mathrm{mmol}, \mathrm{HCl}: 151.3 \mathrm{mmol}, \mathrm{H}_{2} \mathrm{O}_{2}\left(30 \%\right.$ aq. solution): $4.05 \mathrm{ml}, 39.7 \mathrm{mmol}, \mathrm{H}_{2} \mathrm{O}: 9.8 \mathrm{ml}, 3 \mathrm{~h} .{ }^{b}$ Conversion $(\%)=[$ the converted 1a $(\mathrm{mol}) /$ initial 1a $(\mathrm{mol})] \times 100 .{ }^{c}$ Total yield $(\%)=[$ all products $(\mathrm{mol}) /$ initial 1a $(\mathrm{mol})] \times 100 .{ }^{d}$ Yield $(\%)=[$ target product $(\mathrm{mol}) /$ initial $1 \mathrm{a}$ $(\mathrm{mol})] \times 100 .{ }^{e} \mathrm{HCl}: 50.4 \mathrm{mmol} .{ }^{f} \mathrm{HCl}: 50.4 \mathrm{mmol}, \mathrm{H}_{2} \mathrm{O}_{2}\left(30 \%\right.$ aq. solution): $6.08 \mathrm{ml}, 58.8 \mathrm{mmol} .{ }^{g} \mathrm{HCl}: 44.7 \mathrm{mmol}, \mathrm{H}_{2} \mathrm{O}_{2}(30 \%$ aq. solution): $6.08 \mathrm{ml}$, 58.8 mmol. ${ }^{h} \mathrm{HCl}: 42.6 \mathrm{mmol}, \mathrm{H}_{2} \mathrm{O}_{2}\left(30 \%\right.$ aq. solution): $4.35 \mathrm{ml}, 42.6 \mathrm{mmol} .{ }^{i}$ Under $\mathrm{Ar}$ atmosphere. ${ }^{j} \mathrm{HCl}: 42.6 \mathrm{mmol}, \mathrm{H}_{2} \mathrm{O}_{2}$ (30\% aq. solution): $6.08 \mathrm{ml}, 58.8 \mathrm{mmol} .{ }^{k} \mathrm{HCl}: 44.7 \mathrm{mmol}, \mathrm{H}_{2} \mathrm{O}_{2}$ (30\% aq. solution): $8.10 \mathrm{ml}, 79.4 \mathrm{mmol}$.

Table 3 Recycle test results of the catalyst ${ }^{a}$

\begin{tabular}{lllllllll}
\hline & & & \multicolumn{3}{c}{ Yield $^{d}(\%)$} \\
\cline { 4 - 7 } Run time & Conversion $^{b}(\%)$ & $\operatorname{Total~yield~}^{c}(\%)$ & $\mathbf{1 b}$ & $p$ - & $o-$ & $\mathbf{1 c}$ \\
\hline 1 & 100 & 95 & 91 & 1 & Trace & 3 \\
3 & 100 & 94 & 90 & 1 & Trace & 2 \\
6 & 98 & 92 & 88 & 2 & Trace & 1
\end{tabular}

${ }^{a}$ Reaction conditions: $1 \mathrm{a}: 21.3 \mathrm{mmol}, \mathrm{MnSO}_{4}: 1 \mathrm{~mol} \%$, HCl: $44.7 \mathrm{mmol}$, $\mathrm{H}_{2} \mathrm{O}_{2}$ (30\% aq. solution): $6.08 \mathrm{ml}, 58.8 \mathrm{mmol}, \mathrm{H}_{2} \mathrm{O}: 9.8 \mathrm{ml}, 80{ }^{\circ} \mathrm{C}, 3 \mathrm{~h}$. ${ }^{b}$ Conversion $(\%)=[$ the converted 1a $(\mathrm{mol}) /$ initial 1a $(\mathrm{mol})] \times 100$. ${ }^{c}$ Total yield $(\%)=[$ all products $(\mathrm{mol}) /$ initial 1a $(\mathrm{mol})] \times 100 .{ }^{d}$ Yield $(\%)=[$ target product $(\mathrm{mol}) /$ initial $1 \mathrm{a}(\mathrm{mol})] \times 100$.

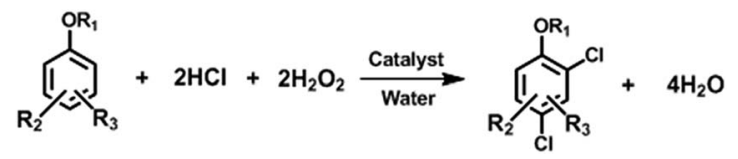

Scheme 5 Oxychlorination for the synthesis of 2,4-dichlorosubstituted phenol derivatives with $\mathrm{H}_{2} \mathrm{O}_{2}$ under VOC-free conditions.

mol\% of $\mathrm{MnSO}_{4}$ resulted in lower total yields due to overoxidation. When the amount of $\mathrm{HCl}$ was reduced and $\mathrm{HCl}: \mathrm{H}_{2} \mathrm{O}_{2}: 1 \mathrm{a}$ was varied to $2.4: 1.9: 1$, the conversion of $1 \mathrm{a}$ was $76 \%$ with a total yield of $74 \%$, containing $9 \%$ of $1 \mathbf{b}, 39 \%$ of $p$-, 25\% of $o$ - and trace 1c (Table 2, run 4). A large excess amount of $\mathbf{H C l}$ promotes the formation of $\mathbf{1 b}$. The effect of temperature was tested at a $\mathrm{HCl}: \mathrm{H}_{2} \mathrm{O}_{2}:$ 1a ratio of $2.4: 1.9: 1$ (Table 2, run $5-8)$. As the temperature was increased from $45{ }^{\circ} \mathrm{C}$ to $90{ }^{\circ} \mathrm{C}, 1 \mathrm{a}$ was completely converted at $80{ }^{\circ} \mathrm{C}$ and the total yield was $95 \%$; the yield for $\mathbf{1 b}$ reached a maximum of $72 \%$ with $13 \%$ of $p-, 9 \%$ of $o$ - and $3 \%$ of 1c. Further increasing the temperature to $90{ }^{\circ} \mathrm{C}$ resulted in over-oxidation and the total yield decreased to $83 \%$. Thus, $80{ }^{\circ} \mathrm{C}$ is desirable for the reactions.

When we increased the amount of $\mathrm{H}_{2} \mathrm{O}_{2}$, i.e. the ratio of $\mathrm{HCl}: \mathrm{H}_{2} \mathrm{O}_{2}$ : 1a was varied from $2.4: 1.9: 1$ to $2.4: 2.8: 1$, the yield of $\mathbf{1 b}$ reached as high as $93 \%$ with $1 \%$ of $p$-, trace $o$ - and $3 \%$ of 1c (Table 2, run 9). If $\mathrm{HCl}$ was further decreased and $\mathrm{HCl}: \mathrm{H}_{2} \mathrm{O}_{2}: 1 \mathrm{a}$ was tuned to $2.1: 2.8: 1$, the total yield was $95 \%$, and the yield for $1 \mathrm{~b}$ was $91 \%$ with $1 \%$ of $p$-, trace $o$ - and $3 \%$ of 1c (Table 2, run 10). In the absence of $\mathrm{MnSO}_{4}$, the full conversion of 1a with a total yield of $96 \%$ was achieved, and the yield for 1b was $34 \%$ with $39 \%$ of $p$-, $23 \%$ of $o$ - and trace $1 \mathbf{c}$ (Table 2, run 11). When the reaction was carried out based on the theoretical equation (Scheme 4), i.e. $\mathrm{HCl}: \mathrm{H}_{2} \mathrm{O}_{2}$ : 1a was $2.0: 2.0: 1,85 \%$ of 1 a was converted with a total yield of $83 \%$, and the products were $58 \%$ of $1 \mathrm{~b}, 15 \%$ of $p$-, $10 \%$ of $o$ - and $1 \%$ of 1c (Table 2, run 13). In the absence of $\mathrm{MnSO}_{4}, 94 \%$ of $1 \mathrm{a}$ was converted with a total yield of $91 \%$, containing $31 \%$ of $\mathbf{1 b}, 35 \%$ of $p$-, 25\% of $o$ - and trace 1c (Table 2, run 12). Obviously, the presence of $\mathrm{MnSO}_{4}$ significantly increased the yield of $\mathbf{1 b}$, and hence $\mathrm{MnSO}_{4}$ is key for the selective chlorination of $\mathbf{1 a}$ to $\mathbf{1 b}$. When the reaction was performed under an Ar atmosphere (Table 2, run 14), the results were comparable with those in air (Table 2, run 10), so oxygen has no effect on the reactions. If $\mathbf{1 a}$ was chlorinated based on a ratio of $\mathrm{HCl}: \mathbf{1 a}$ at $2.0: 1$, the yield of $1 \mathbf{b}$ was $85 \%$ with $3 \%$ of $p$-, $2 \%$ of $o$ - and $2 \%$ of $1 \mathrm{c}$ (Table 2, run 15). As a large excess amount of $\mathrm{H}_{2} \mathrm{O}_{2}$ was used $\left(\mathrm{HCl}: \mathrm{H}_{2} \mathrm{O}_{2}\right.$ $: \mathbf{1 a}=2.1: 3.7: 1$ ), over-oxidation occurred and the total yield decreased to $88 \%$ (Table 2, run 16). Because the decomposition of $\mathrm{H}_{2} \mathrm{O}_{2}$ is inevitable, the used amount of $\mathrm{H}_{2} \mathrm{O}_{2}$ in the reaction is higher than the theoretical value. The utilization of $\mathrm{H}_{2} \mathrm{O}_{2}$ and 


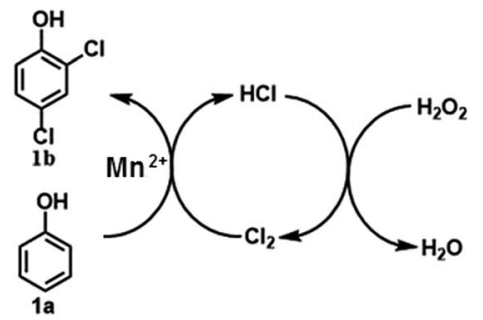

Scheme 6 A reaction pathway of the oxychlorination of phenol over an $\mathrm{Mn}^{2+}$ catalyst.

$\mathrm{HCl}$ based on the optimized conditions (Table 2, run 10) is $66 \%$ and $87 \%$, respectively.

When $\mathrm{HCl}: \mathrm{H}_{2} \mathrm{O}_{2}:$ 1a was $3.1: 4.2: 1$, full conversion of $\mathbf{1 a}$ was achieved at $80{ }^{\circ} \mathrm{C}$ for $3 \mathrm{~h}$ and the total yield was $91 \%$, the yield for 2,4,6-trichlorophenol was $73 \%$ with $11 \%$ of $1 \mathbf{b}, 7 \%$ of 1c and trace $p$ - and $o$-. If $\mathrm{HCl}: \mathrm{H}_{2} \mathrm{O}_{2}: \mathbf{1 a}$ was increased to $3.5: 4.2: 1$, full conversion of 1 a with a total yield of $94 \%$ was obtained, and $80 \%$ of 2,4,6-trichlorophenol with $6 \%$ of $\mathbf{1 b}$ and $8 \%$ of $1 \mathrm{c}$ were found as the products. Thus, while the performance of $\mathrm{MnSO}_{4}$ is better in the synthesis of $\mathbf{1 b}$, it is also active in the synthesis of 2,4,6-trichlorophenol.

In our experiments, we found that the reagents formed a homogeneous solution before reaction, and two discrete phases were observed at the end of the reaction. The top phase is an aqueous solution containing the catalyst, and the lower is an organic phase mainly composed of $\mathbf{1 b}, p$-, $o$ - and $1 \mathbf{c}$. This means that the products automatically come out from the aqueous solution. This property is really convenient for product collection via phase separation. Moreover, since $\mathrm{MnSO}_{4}$ remains in the aqueous solution, recycling of the catalyst is simple.

In fact, commercial hydrochloric acid can be directly used rather than gaseous $\mathrm{HCl}$ in the reactions, as similar results were also obtained under the optimized conditions. However, we think that the use of gaseous $\mathrm{HCl}$ is more economical, particularly for large scale production. If hydrochloric acid is used, the products can be obtained by phase separation, but the collection of the catalyst requires the removal the whole aqueous solution via evaporation. Then, the collected catalyst, 1a and hydrochloric acid are mixed for the next run. As gaseous $\mathrm{HCl}$ is used, the products were isolated by phase separation, the remaining aqueous solution was concentrated by removing excess water from the solution of $\mathrm{H}_{2} \mathrm{O}_{2}$ under reduced pressure, and gaseous $\mathrm{HCl}$ was introduced into the concentrated solution. Then, 1a is added for the next run. Compared with gaseous $\mathrm{HCl}$, it is clear that more water needs to be evaporated when using hydrochloric acid.

Based on the optimized conditions, the recycle test results of the catalyst are shown in Table 3. After each run, the same procedure was performed until the catalyst was used 6 times. These results indicate that the catalyst was recyclable, and no significant decrease in activity was observed even after 6 runs.

Since 2,4-dichloro-substituted phenol derivatives present a series of valuable materials for fine chemicals, this method was further used in the chlorination of various phenol derivatives (see ESI, Table 1S $\dagger$ ). Although monochloro-substituted phenols, such as $p$ - and $o$-, are undesirable products in our reactions, these compounds can be efficiently converted into $\mathbf{1 b}$ in our method. Complete conversion of $p$ - was obtained in a high yield of $96 \%$ for $\mathbf{1 b}$, and the yield of $\mathbf{1 b}$ was $94 \%$ for the total conversion of $o$-. Thus, monochloro-substituted phenols can be effectively utilized, and the by-product that remains in our system is only 1c. As for bromo- or iodo-substituted phenols, side-reactions of debromination/deiodination occurred and resulted in a complex mixture. This method is effective for alkylphenols, which were successfully chlorinated as various 2,4-dichlorophenols. A yield of $75 \%$ was achieved for $3 \mathbf{b}$ from $o$-cresol (3a), and an $81 \%$ yield for $\mathbf{4 b}$ was obtained from 2-tert-butylphenol (4a). Complete conversion of $5 \mathbf{a}(3,5$ dimethylphenol) was achieved, and the yield for $\mathbf{5 b}$ was $86 \%$. The chlorination of ethers of phenol can also be easily performed under similar conditions. Complete conversion of anisole (6a) led to a yield of $82 \%$ for $\mathbf{6 b}$, and a high yield of $81 \%$ for 7b was achieved from 3,5-dimethylanisole (7a). Thus, we consider that our study offers a versatile synthetic method in the manufacture of various 2,4-dichlorophenol derivatives (Scheme 5).

The molar ratio of $\mathrm{H}_{2} \mathrm{O}_{2}: \mathbf{1 a}$ was $2: 1$ according to the theoretical equation (Scheme 4), but it was 2.8:1 under the optimized conditions (Table 2, run 10). The used amount of $\mathrm{H}_{2} \mathrm{O}_{2}$ is higher than the theoretical value. It is well known that the catalytic decomposition of $\mathrm{H}_{2} \mathrm{O}_{2}$ over metal ions is inevitable, and the interactions of $\mathrm{Mn}^{2+}$ with $\mathrm{H}_{2} \mathrm{O}_{2}$ lead to numerous reactive species, such as oxygen atoms, active oxygen species or $\mathrm{OH}^{*} / \mathrm{OOH}^{*}$ radicals, which are possible active species for reactions. In our experiments, when a free radical scavenger, 2,6-ditert-butyl-4-methyl phenol, was added into the reactions, the yield of $\mathbf{1 b}$ significantly decreased to $30 \%$. Although this result indicates that a free radical pathway is possibly involved in the reactions, our attempts to find out the free radicals or active species failed because of the complexity of this system. In controlled experiments, we found that the addition of $\mathrm{H}_{2} \mathrm{O}_{2}$ into an aqueous solution of $\mathrm{HCl}$ immediately resulted in light yellow gas, which was $\mathrm{Cl}_{2}$ based on GC-MS analysis. Thus, while the exact free radicals or active species are not yet clear, the main pathway can be presented as shown in Scheme 6: $\mathrm{HCl}$ is oxidized by $\mathrm{H}_{2} \mathrm{O}_{2}$ to $\mathrm{Cl}_{2}$; the generated $\mathrm{Cl}_{2}$ reacts with 1 a to form 1b with the release of $\mathrm{HCl}$, which is re-oxidized and re-used until 1a is exhausted. Details of the reaction mechanism are under investigation, and we will report the results in future.

\section{Conclusions}

In summary, we have developed a simple, mild and efficient method for oxychlorination of phenol to 2,4-dichlorophenol catalyzed by manganous(II) sulfate in the liquid phase. In this system, hydrogen chloride was used as a chlorinating agent, hydrogen peroxide as an oxidant and water as a solvent. We envisage that our method will be effective in the manufacture of various 2,4-dichlorophenol derivatives based on the following 
reasons: (1) high activity and selectivity; (2) VOC free; (3) simple product separation and recyclable catalyst.

\section{Experimental section}

\section{Typical procedure for oxychlorination of phenol}

Phenol and a catalyst were added to water in a three-neck flask equipped with a gas inlet, a liquid inlet and a reflux condenser (open to air). Gaseous $\mathrm{HCl}$ was introduced and dissolved as an aqueous solution. The flask was immersed in a preheated oil bath and vigorously stirred with a magnetic stirrer. Then, $\mathrm{H}_{2} \mathrm{O}_{2}$ (30\% aq. solution) was added dropwise by a channel pump during the reaction. At the end of the reaction, the mixtures were left to stand for $1.5 \mathrm{~h}$, and an isolated organic phase from the aqueous solution formed at the bottom. The organic phase was collected and diluted with acetonitrile to prepare the sample for quantitative analysis. The conversions and yields were determined by gas chromatography. Each experiment was reproduced at least three times. The experimental error in the determination of the conversions and yields normally did not exceed $4 \%$. Pure products were obtained by column chromatography using silica gel (petroleum ether) and confirmed by GC-MS, ${ }^{1} \mathrm{H}$ and ${ }^{13} \mathrm{C}$ NMR.

\section{${ }^{1} \mathrm{H}$ NMR and ${ }^{13} \mathrm{C}$ NMR analytical data of products}

2,4-Dichlorophenol. ${ }^{1} \mathrm{H}$ NMR $\left(600 \mathrm{MHz}, \mathrm{CDCl}_{3}\right) \delta: 7.32(\mathrm{~d}, J=$ $2.4 \mathrm{~Hz}, 1 \mathrm{H}), 7.15$ (dd, $J=2.4,9.6 \mathrm{~Hz}, 1 \mathrm{H}), 6.95(\mathrm{~d}, J=9.0 \mathrm{~Hz}$, $1 \mathrm{H}), 5.51(\mathrm{~s}, 1 \mathrm{H}) ;{ }^{13} \mathrm{C}$ NMR $\left(150 \mathrm{MHz}, \mathrm{CDCl}_{3}\right) \delta: 150.2,128.6$, 128.56, 125.6, 120.4, 117.1.

4-Chlorophenol. ${ }^{1} \mathrm{H}$ NMR $\left(600 \mathrm{MHz}, \mathrm{CDCl}_{3}\right) \delta: 7.19(\mathrm{~d}, J=$ $9.0 \mathrm{~Hz}, 2 \mathrm{H}), 6.76(\mathrm{~d}, J=8.4 \mathrm{~Hz}, 2 \mathrm{H}), 4.90(\mathrm{~s}, 1 \mathrm{H}) ;{ }^{13} \mathrm{C}$ NMR $(150$ $\left.\mathrm{MHz}, \mathrm{CDCl}_{3}\right) \delta: 154.1,129.6,125.7,116.7$.

2-Chlorophenol. ${ }^{1} \mathrm{H}$ NMR (600 MHz, $\left.\mathrm{CDCl}_{3}\right) \delta: 7.29(\mathrm{~m}, 1 \mathrm{H})$, $7.16(\mathrm{~m}, 1 \mathrm{H}), 7.01(\mathrm{~m}, 1 \mathrm{H}), 6.85(\mathrm{~m}, 1 \mathrm{H}), 5.62(\mathrm{~s}, 1 \mathrm{H}) ;{ }^{13} \mathrm{C} \mathrm{NMR}$ $\left(150 \mathrm{MHz}, \mathrm{CDCl}_{3}\right) \delta: 151.4,129.1,128.5,121.4,119.9,116.3$.

2,6-Dichlorophenol. ${ }^{1} \mathrm{H}$ NMR $\left(600 \mathrm{MHz}, \mathrm{CDCl}_{3}\right) \delta: 7.26(\mathrm{~d}, J=$ $7.8 \mathrm{~Hz}, 2 \mathrm{H}), 6.82(\mathrm{t}, J=8.4 \mathrm{~Hz}, 1 \mathrm{H}), 5.85(\mathrm{~s}, 1 \mathrm{H}) ;{ }^{13} \mathrm{C}$ NMR $(150$ $\left.\mathrm{MHz}, \mathrm{CDCl}_{3}\right) \delta: 147.9,128.3,121.2,121.1$.

2,4,6-Trichlorophenol. ${ }^{1} \mathrm{H}$ NMR $\left(600 \mathrm{MHz}, \mathrm{CDCl}_{3}\right) \delta: 7.28(\mathrm{~s}$, $2 \mathrm{H}), 5.81(\mathrm{~s}, 1 \mathrm{H}) ;{ }^{13} \mathrm{C}$ NMR (150 MHz, $\left.\mathrm{CDCl}_{3}\right) \delta: 146.9,128.1$, 125.4, 121.6.

2,4-Dichloro-6-methylphenol. ${ }^{1} \mathrm{H}$-NMR $\left(600 \mathrm{MHz}, \mathrm{CDCl}_{3}\right) \delta$ : $7.16(\mathrm{~d}, J=2.4 \mathrm{~Hz}, 1 \mathrm{H}), 7.02(\mathrm{~d}, J=2.4 \mathrm{~Hz}, 1 \mathrm{H}), 5.24(\mathrm{~s}, 1 \mathrm{H}), 2.26$ (s, 3H); ${ }^{13} \mathrm{C}$ NMR $\left(150 \mathrm{MHz}, \mathrm{CDCl}_{3}\right) \delta: 148.4,129.6,127.3,125.8$, 124.7, 119.8, 16.3.

2,4-Dichloro-6-t-butylphenol. ${ }^{1} \mathrm{H}-\mathrm{NMR}\left(600 \mathrm{MHz}, \mathrm{CDCl}_{3}\right) \delta$ : $7.20(\mathrm{~d}, J=2.4 \mathrm{~Hz}, 1 \mathrm{H}), 7.15(\mathrm{~d}, J=2.4 \mathrm{~Hz}, 1 \mathrm{H}), 5.80(\mathrm{~s}, 1 \mathrm{H}), 1.38$ (s, 9H); ${ }^{13} \mathrm{C}$ NMR $\left(150 \mathrm{MHz}, \mathrm{CDCl}_{3}\right) \delta: 148.5,138.9,126.2,125.9$, 124.7, 121.1, 35.5, 29.1.

2,4-Dichloro-3,5-dimethylphenol. ${ }^{1} \mathrm{H}-\mathrm{NMR}\left(600 \mathrm{MHz}, \mathrm{CDCl}_{3}\right)$ $\delta: 6.80(\mathrm{~s}, 1 \mathrm{H}), 5.48(\mathrm{~s}, 1 \mathrm{H}), 2.46(\mathrm{~s}, 3 \mathrm{H}), 2.32(\mathrm{~s}, 3 \mathrm{H}) ;{ }^{13} \mathrm{C}$ NMR $\left(150 \mathrm{MHz}, \mathrm{CDCl}_{3}\right) \delta: 149.5,136.0,134.2,126.5,118.5,115.1$, 20.8, 18.3.

2,4-Dichloroanisole. ${ }^{1} \mathrm{H}$ NMR $\left(600 \mathrm{MHz}, \mathrm{CDCl}_{3}\right) \delta: 7.34(\mathrm{~d}, J=$ $2.4 \mathrm{~Hz}, 1 \mathrm{H}), 7.19$ (dd, $J=2.4,9.0 \mathrm{~Hz}, 1 \mathrm{H}), 6.82(\mathrm{~d}, J=9.0 \mathrm{~Hz}$,
1H), $3.86(\mathrm{~s}, 3 \mathrm{H}) ;{ }^{13} \mathrm{C}$ NMR (150 MHz, $\left.\mathrm{CDCl}_{3}\right) \delta: 153.9,129.9$, 127.9, 125.6, 123.2, 112.8, 56.3.

2,4-Dichloro-3,5-dimethylanisole. ${ }^{1} \mathrm{H}$ NMR $\left(600 \mathrm{MHz}, \mathrm{CDCl}_{3}\right)$ $\delta: 6.67(\mathrm{~s}, 1 \mathrm{H}), 3.86(\mathrm{~s}, 3 \mathrm{H}), 2.47(\mathrm{~s}, 3 \mathrm{H}), 2.36(\mathrm{~s}, 3 \mathrm{H}) ;{ }^{13} \mathrm{C} \mathrm{NMR}$ $\left(150 \mathrm{MHz}, \mathrm{CDCl}_{3}\right) \delta: 153.2,136.3,134.9,126.8,120.9,111.4$, $59.3,21.2,18.2$.

\section{Acknowledgements}

We are thankful for the funding support from the Innovative Research Team in College and Universities of Liaoning Province (No. LT2014007).

\section{Notes and references}

1 Kirk-Othmer Encyclopedia of Chemical Technology, Wiley, New York, 6th edn, 1993, vol. 5.

2 Ullmann's Encyclopedia of Industrial Chemistry, Wiley-VCH, Weinheim, 6th edn, 1998.

3 A. Białek and W. Moszczyński, Pol. J. Chem. Technol., 2009, 11(2), 21-30.

4 W. D. Watson, J. Org. Chem., 1985, 50(12), 2145-2148.

5 S. Ratton and J.-C. Leblanc, European Patent, 0196260, 1986. 6 P. V. Vyas, A. K. Bhatt, G. Ramachandraiah and A. V. Bedekar, Tetrahedron Lett., 2003, 44(21), 4085-4088.

7 C. Chiappe, E. Leandri and M. Tebano, Green Chem., 2006, 8, 742-745.

8 J. G. P. Born, H. W. A. V. D. Wart, P. Mulder and R. Louw, Recl. Trav. Chim. Pays-Bas, 1993, 112, 262-270.

9 B. S. Samant, Y. P. Saraf and S. S. Bhagwat, J. Colloid Interface Sci., 2006, 302(1), 207-213.

10 L. Yang, L. Zhan and S. S. Stahl, Chem. Commun., 2009, 64606462.

11 X. Sun, G. Shan, Y. Sun and Y. Rao, Angew. Chem., Int. Ed., 2013, 52(16), 4440-4444.

12 Y. Goldberg and H. Alper, J. Org. Chem., 1993, 58(11), 30723075.

13 L. Delaude and P. Laszlo, J. Org. Chem., 1990, 55(18), 52605269.

14 S. R. Bansal, D. C. Nonhebel and J. M. Mancilla, Tetrahedron, 1973, 29(7), 993-999.

15 X. Wan, Z. Ma, B. Li, K. Zhang, S. Cao, S. Zhang and Z. Shi, J. Am. Chem. Soc., 2006, 128(23), 7416-7417.

16 D. Niu, T. Wang, B. P. Woods and T. R. Hoye, Org. Lett., 2014, 16(1), 254-257.

17 J. S. Grossert and G. K. Chip, Tetrahedron Lett., 1970, 11(30), 2611.

18 K. M. Brummond and K. D. Gesenberg, Tetrahedron Lett., 1999, 40(12), 2231-2234.

19 J. R. L. Smith, L. C. Mckeer and J. M. Taylor, J. Chem. Soc., Perkin Trans. 2, 1988, 10, 1533-1537.

20 B. S. Moon, Y. C. Han, H. Y. Koh and D. Y. Chi, Bull. Korean Chem. Soc., 2011, 32(2), 472-476.

21 G. Majetich, R. Hicks and S. Reister, J. Org. Chem., 1997, 62(13), 4321-4326.

22 R. Prebil, K. K. Laali and S. Stavber, Org. Lett., 2013, 15(9), 2108-2111. 
23 Y. Xiong, H. Duan, X. Meng, Z. Ding and W. Feng, J. Chem., 2016, 2016, 1-5.

24 C. U. Dinesh, R. Kumar, B. Pandey and P. Kumar, J. Chem. Soc., Chem. Commun., 1995, 6, 611-612.

25 N. B. Barhate, A. S. Gajare, R. D. Wakharkar and A. V. Bedekar, Tetrahedron Lett., 1998, 39(35), 6349-6350.

26 N. B. Barhate, A. S. Gajare, R. D. Wakharkar and A. V. Bedekar, Tetrahedron, 1999, 55(36), 11127-11142.

27 N. Narender, P. Srinivasu, S. J. Kulkarni and K. V. Raghavan, Synth. Commun., 2002, 33, 279-286.
28 B. S. Bhatkhande, M. V. Adhikari and S. D. Samant, Ultrason. Sonochem., 2002, 9(1), 31-35.

29 L. K. Liu and C. S. Lin, J. Chin. Chem. Soc., 1996, 43(1), 61-66. 30 L. Menini and E. V. Gusevskaya, Appl. Catal., A, 2006, 309(1), 122-128.

31 L. Menini and E. V. Gusevskaya, Chem. Commun., 2006, 209211.

32 R. Raja and P. Ratnasamy, J. Catal., 1997, 170(2), 244-253.

33 A. Podgorsek, M. Zupan and J. Iskra, Angew. Chem., Int. Ed., 2009, 48(45), 8424-8450. 